Hans, J. v. Der jährliche Gang der Luitelektrizität auf der südlichen Halbkugel. Meteor. Zs., Braunschweig, v. 30, No. 1, Jan., 1913, Kl. Mitt. (30).

MülLy, C. Über Elektrometer von hoher Empfindlichkeit. Physik. Zs., Leipzig, v. 14, No. 6, Mar. 15, $1913(237-240)$.

Rudge, W. A. Douglas. Atmospheric electrification during South African dust storms. Letter to the editor. Nature, London, v. 91. No. 2263, Mar. 13, 1913 (31-32).

\title{
RADLER DE AQUINO'S NEWEST NAVIGATION ALTITUDE AND AZIMUTH TABLES.
}

The fact that this latest book by Lieut. Radler de Aquino, of the Brazilian Navy, offers ready solutions, without the use of logarithnus, for nearly all the problems of navigation, that the method used is general for all solutions, and that it contains in compact form all the necessary tables, should make it popular, and especially so to the navigator who dislikes to use logarithms.

After the tables are once thoroughly understood and the various precepts remembered, they can be used very readily, being particularly valuable for star sights, when two or more stars are observed simultaneously, for star identification, and for obtaining corrections for variations in data.

The addition of a plane traverse table and of the various correction tables common to navigation, is to be commended, making the book more nearly a universal solver for the navigator. The more open and extensive traverse table of the "American Practical Navigator" may be preferred by some as more convenient. However, the more extensive tables contemplated by the author will add much to the speed and accuracy of the method.

J. P. Ault.

'AQUiNo, RADLER DE. The "newest" navigation altitude and aximuth tables for facilitating the determination of lines of position and geographical position at sea. The simplest and readiest in solution. Plane and spherical traverse tables for solving all problems of navigation. Second stereotyped edition. Enlarged and improved. London, J. D. Potter; Rio de Janeiro, D. Norris, 1912 (xlix $+176+12$ ). $25 \mathrm{~cm}$. New $\log$ and versine altitude tables. (Reprinted from the author's "The 'newest' navigation altitude and azimuth tables," $2 d$ edition, 1912). l.ondon, J. D. Potter; Rio de Janeiro, D. Norris, 1912 (circa $40+11$ ). $25 \mathrm{~cm}$. 